\title{
The characteristics of the most troublesome mosquito species (Diptera: Culicidae) in Poland
}

\author{
Elżbieta WEGNER \\ Museum and Institute of Zoology, Polish Academy of Sciences, Wilcza 64, Warszawa, Poland; \\ e-mail: wegner@mizz.waw.pl
}

\begin{abstract}
Twelve of the 47 Polish mosquito species can pose serious health problems to man or at least heavy nuisance. They fly from breeding sites (where huge numbers can be produced) into houses and/or farm buildings transmitting severe human and animal diseases. Problematic ones are: Anopheles messae and An. atroparvis, Ochlerotatus communis, Oc. cataphylla, Oc. punctor, Oc. cantans, Oc. sticticus, Aedes cinereus, Ae. vexans, Coquillettidia richiardii, Culex pipiens and Culiseta anmulata. The problems of distribution, phenology under different climatic conditions, habitat requirements and preferences both of larvae and adults, behaviour, fertility and vector competence of all these species are analyzed. Most of the species in the Temperate Zone produce more than one generation during the growing season or at least have several emergences. Only $O c$. communis and $O c$. cataphylla are early spring univoltine species, although they can breed twice or more during the growing season when there are favourable conditions. Univoltine Oc. cantans, which can develop several times during a season, occurring in the breeding sites often together with multivoltine Oc. punctor. The period of their occurrence is usually much longer than that of Oc. communis and Oc. cataphylla. Flood-water mosquitoes - Oc. sticticus and both Aedes species occur along river valleys and their larvae can breed in different pools situated in a variety of environments. Culex pipiens, especially its form molestus and Culiseta annulata can breed in natural and artificial ponds, even in heavily polluted water. Although mosquitoes are known to be competent vectors of serious human and animal diseases, in Poland they are considered to cause nuisance only. Despite the fact that malaria was eradicated in Poland in 1960-s, at least two Polish anopheline species can still transmit the human malarial parasite very effectively. The remaining species (except for only one) described in the paper can transmit several arboviruses, while several species are vectors of filariosis (Dirofilaria sp.).
\end{abstract}

Key words: mosquito, Culicidae, Poland, vectors, arbovirus, filariosis

\section{INTRODUCTION}

Mosquitoes are being studied very thoroughly since their role in the transmission of malaria parasite and yellow fever has been discovered. For the last 75 years the number of recognised species has more than doubled, having risen from 1400 (Edwards 1932) to 3490 nowadays (Harbach \& Howard 2007). In Europe 101 species have been registered (Ramsdale \& Snow 1999) and in Poland - 47 species up to now (Wegner 2007). The majority of mosquito species occur in tropical countries where the insects are the known transmitters of malaria, filariasis, dengue, yellow fever and other diseases. Also in the Temperate Zone mosquitoes are the efficient transmitters of malaria parasite and other human pathogens - viruses: West Nile, Sindbis (Ockelbo, Pogosta and Karelian diseases), Inkoo, T̉ahyňa, as well as several other animal pathogens (Hubálek \& Halouzka 1996, Turell et al. 1990). More and more literature data refer to the distribution of West Nile Virus in temperate Europe (Buckley et al. 2003; Hubálek et. al. 1999, 2000, 2008a; Hubálek \& Halouzka 1996, 1999; Linke et al. 2007). There is a potential that WNV occurs in Poland too (Wegner 2004, Hermanowska-Szpakowicz et. al., 2006, Hubálek et al. 2008b).

38 mosquito species out of 47 Polish ones are more or less aggressive to man. Twelve of them may cause serious problems since they can breed into huge numbers and/or are 
the transmitters of severe human and animal diseases. Moreover, they fly from their breeding places into human settlements, houses and/or farm buildings. They are: Anopheles messae Falleroni, 1926 and An. atroparvus van Thiel, 1927 (which form Anopheles maculipennis complex group), Ochlerotatus communis (De Geer, 1776), Oc. cataphylla Dyar, 1916, Oc. punctor (Kirby, 1837), Oc. cantans (Meigen, 1818), Oc. sticticus (Meigen, 1838), Aedes cinereus Meigen, 1818, Ae. vexans (Meigen, 1830), Coqullettidia richiardii (Ficalbi, 1889), Culiseta annulata (Schrank, 1776) and Culex pipiens L. and especially its form molestus Forskal 1775. At the same time most of them are able to migrate over long distance.

\section{CHARACTERISTICS OF SPECIES}

Mosquitoes are studied well and several great elaborations dealing with taxonomy, zoogeography, biology and ecology have been published. Books by Marshall (1938), Martini (1931), Natvig (1948), Peus (1950), Skierska (1963, 1971, 1977), Gutsevitz et al. (1971) and Becker et al. (2003) were the source of general information about the species described in this paper.

\section{Anopheles (Anopheles) maculipennis complex Meig. (malaria mosquito)}

The complex of species in Poland is composed of three species: Anopheles maculipennis s.s. Meigen, 1818, An. messeae and An. atroparvus. The species are widely distributed in Palaearctic Region. Malaria mosquito is rather not recorded in plague numbers, but even if its occurrence in natural environment is observed not to be extremely numerous it may become quite a serious problem because a great percentage of females fly into buildings. They spend daytime hidden in shady places and attack people and animals during the night hours.

Active females occur from March till October or even November and they hibernate as adult females. The seasonal changes of physiological state of females leading to the hibernation are determined by the illumination during their development. If the larvae and pupae are exposed to a short day length they enter diapause, if to the long day length - they develop without diapause. The critical photoperiod inducing diapause differs considerably both in different species and between the populations of the same species in different latitudes - it decreases from the north towards the south within its area of distribution (Vinogradova 1960).

Fertilized females overwinter in natural caves, animal burrows, tree-holes and in cool buildings or cellars often together with the species of genus Culex and Culiseta. Males do not overwinter.

Females are able to migrate, they actively seek for the hosts, feeding predominantly on mammals, including humans. They rarely feed on birds. Females fly into human houses and farm buildings. An. maculipennis complex has been recorded in all of studied towns in Poland (Wegner 2008).

Since the fall of XIX century when Nowicki (1873) first recorded the species in Poland it has been registered all over the territory of the country. Extensive study on malaria vectors carried out in the 1920-s showed that An. maculipennis complex is very common in Poland (Tarwid 1934). However, it was not precisely defined which of the species of Anopheles maculipennis complex the records refer to (impossibility in distinguishing adult females), the phenomenon called "anophelism without malaria" and study on the sibling species (in the areas where the species were distinguished) show that $A n$. messeae predominate over other species of An. maculipennis complex (Kubica-Biernat 2005).

The aquatic stages of $A n$. messeae and An. atroparvus prefer different insolated or partially shaded, relatively clean, permanent or temporary, stagnant or slowly moving waters $(\mathrm{pH}$ neutral to slightly alkaline) (Harksen et al. 1976) supporting algal growth or emergent 
vegetation such as ditches, drains, slow moving rivers, margins of lakes, ponds and marshes. Larval stages of both species may occur in the same location; however, the second one prefers brackish waters, exhibiting a coastal and estuarine distribution.

During last decades An. atroparvus became much less abundant in Poland than before - it seems that its range retreats nowadays (Kubica-Biernat 2005). The almost extinction of An. atroparvus was observed also in western Europe - in the Netherlands (Takken et al. 2002). These may be the fluctuations known to have been associated with short-term climatic changes, which have been observed in several animal species in central Europe (Udvardy 1969). Actually the climate in Poland changed considerably during last ca 20 years exhibiting extremely dry and hot summers.

Both species are multivoltine. In Temperate Zone An. messeae can breed up to 4 generations per season, An. atroparvus is less fertile - up to 3 generations per year (KubicaBiernat 2005). An. messeae is the most common and most abundant anopheline species in the area of the whole country and eagerly bits humans. An. atroparvus is an anthropophilous species too. Both fly into human houses. They spend day-time hidden in shady nooks and corners and attack people at night when sleeping. An. atroparvus prefers to land on the head, especially the face because it is attracted by breath - removal of exhaled $\mathrm{CO}_{2}$ from a human subject eliminates this preference (De Jong \& Knols, 1995). An. maculipennis s.s. is a zoophilous species which bite people in the absence of animals. Females eagerly fly into animal shelters.

All anophelines fly along broken lines, thus it is difficult to find out from which direction a mosquito approaches. Generally, they attack opportunistically and a bite is usually imperceptible.

The two species of the group - An. messeae and An. atroparvus are the known competent vectors of human malaria parasite. Plasmodium vivax, which used to cause the disease in Poland was transmitted almost exclusively by An. messeae and in the seaside region by $A n$. atroparvus (Kubica-Biernat 2005). Some authors show that An. maculipennis s.l. can occasionally be a transmitter of West Nile virus. It is also a possible vector of dog's filariosis, since filarial DNA has been found in examined females but further study is necessary to confirm its vector competence (Cancrini et al. 2006).

\section{Ochlerotatus (Ochlerotatus) cantans (Meig.)}

Univoltine species distributed in forest zone of Palaearctic Region. It is a large size species. Oc. cantans belongs essentially to the fauna of the region of mixed forest (Minár \& Kramár 1980), but it occurs in coniferous and deciduous forests, as well. Oc. cantans is one of the most common species of woods and forests in European lowlands. In mountainous regions it is much less abundant (Wegner 1991, Merdić 1995) or absent (Božičić \& Morović 1987, Kaiser et al. 2001). The species has been recorded in all of study towns of Europe (Wegner 2008).

In northern countries Oc. cantans has only one emergence in the spring, if the second one takes place it is much less numerous (Brummer-Korvenkontio et al. 1971). In Central Europe, the spring emergence began usually at the beginning of May and continues for an average of one month unless the breeding sites dry out earlier. The period of emergence of adults is considerable longer than that of other univoltine snow-melt species. Natvig (1948) reports that in Denmark and southern Fennoscandia imagines occur from the middle of May and the species is extremely common in July and August. In central and southern Europe Oc. cantans is most numerous in June and July, although it may breed in spring, summer or even in autumn (it depends on weather conditions). Michalková \& Halgoš (2005) observed its larvae in Slovakia in May, August and October, while Skierska (1974) observed them in April, May and 
July in western Poland. Also Wojnarowicz (1960), Harksen et. al (1976), Eukasiak (1965) and Wegner $(1979,1999)$ reported summer and autumnal development of the species, when summer storms filled up the breeding ponds. In Croatia the species has three or four annual peaks (Sudarić Bogojević et al. 2008).

Wojnarowicz $(1960)$ and Wegner $(1979,1999)$ pointed out that summer and autumnal emergences of the species are clearly associated with rainfall. Wojnarowicz maintained that summer and autumnal larvae must hatch from the eggs, which were lied previous summer high above the usual water level of the pond. Laboratory and field studies confirmed this thesis and showed that the phenomenon is not an example of mulivoltinism, but is an effect of successive hatching (Service 1977). Nevertheless, in Poland Oc. cantans is a species typical of spring and summer season and the females are on wings for several months.

As a large-size species, females took large blood portions although there is no distinct correlation in Oc. cantans between body weight and blood-meal size (Service 1968). Service (1977) observed that in Great Britain maximum numbers of Oc. cantans are feeding from June to August, similarly as it takes place in Poland. In the temperature typical of this period in Poland a blood-meal is digested within about six-eight days. Thus females are able to feed about every seven-nine days. A proportion of females require two blood-meals for maturation for the first batch of eggs, but thereafter one blood-meal suffices.

Fecundity and a number of eggs in successive ovipositions decreases with a decrease of female size - within a range from 23 (small females) up to 78 eggs (largest females) (Service 1968). Females deposit eggs among leaf litter in woodland hollows that collect water during the snow-melting and spring rains. The eggs stay able to develop for several years (Becker et al. 2003). The species overwinters in the egg stage.

Larvae develop in shady, permanent and temporary pools rich in organic matter, with decaying leaves from April till August or even September. They often co-exist with larvae of some other Ochlerotatus species (i.e. Oc. communis, Oc. punctor, Oc. cataphylla). They breed in pools situated in different habitats, mainly in forests, but also in open sites, even in brackish and polluted water (Brummer-Korvenkontio et at. 1971, Harksen et al. 1976, Skierska 1974). According to Brummer-Korvenkontio et al. (1971) larvae prefer neutral $\mathrm{pH}$ of water but can breed in alkaline and saline waters as well. Natvig (1948) reports larvae of Oc. cantans in water $\mathrm{pH}=6.7-7.5$. Harksen et al. (1976) observed larvae in pools with water $\mathrm{pH}=4.1-7.6$. Only Skierska (1965) qualified Oc. cantans as acidophilous and stenoionic in Baltic coastal forest belt while in other her studies she points out that the species breeds in different pools situated in different habitats often with numerous other Ochlerotatus species. Larvae avoid only those pools, which are the breeding sites of An. maculipennis, $C_{X}$. pipiens, $C_{X}$. modestus, Cs. alaskaensis and Oc. dorsalis (Skierska 1974). Laboratory experiments and field observations showed that larvae of the species maintained at high densities showed increased mortality and reduced size (Renshaw et al. 1993, 1994).

Most females die after oviposition but the remaining can lie more batches of eggs if they have a blood meal (Service 1977). Adult females occur from May till September or even October in different habitats in forests and open areas close to breeding sites of the species. Observations made by Dąbrowska-Prot (1962) and Service (1977) show that the females of Oc. cantans do not penetrate open areas distant from woods and forests. Skierska (1974) showed, that females fly into those farm buildings which are situated in the forest, close to the breeding sites. Dąbrowska-Prot (1966) who studied vertical distribution of mosquitoes during night hours in the Kampinos Forest observed that females of the species most numerously occur among shrubs and young trees although some of them also penetrate the canopy (but rather avoid flying over the canopy). Also Service (1971a) reported that Oc. cantans keeps rather low, close to the ground. 
In lowland Poland the species commonly predominates in late spring and summer mosquito communities in forest areas (Karczewski \& Krzemiński 1965; Kubica-Biernat \& KowalskaUlczyńska 2006; Kowalska-Ulczyńska \& Gilka 2003; Lukasiak 1959; Okróy-Rysop et al. 1991; Skierska 1960, 1965, 1974; Skierska \& Lachmajer 1960; Wegner 1979, 1982, 2002).

Females are troublesome biters outdoors, with peak biting around sunrise and sunset. The sunset maximum is greatly higher than the sunrise one (Service 1971a).

Service $(1971 b, 1977)$ showed that Oc. cantans feeds mainly on rabbits and to the lesser degree on bovines, man and other mammals, as well as on birds. Later study of Keith Snow (personal comm.) with use of baited traps with rabbits, grey squirrels, chickens and wood pigeons showed that $O c$. cantans was attracted to all of them. That means that females generally feed on any available host. They also bite humans readily.

It is accepted that the vector potential depends on multiple blood feeding, which is necessary for the development of eggs. Thus Shlenova \& Bei-Bienko (1962) examined the potential of different species to multiple oviposition and they found out that the maximal number of ovipositions recorded for Oc. cantans was seven.

Oc. cantans is a competent vector of arboviruses: Ťahyňa and West Nile. West Nile virus has been isolated from Oc. cantans in Slovakia (Labuda et al. 1974).

\section{Ochlerotatus (Ochlerotatus) cataphylla Dyar}

Univoltine early spring species common in north Holarctic region. Natvig (1948) qualifies it as a species, which occur in both lowland and mountainous regions (in Norway up to $620 \mathrm{~m}$ a.s.1.), a species, which prefers temporary ponds of plains and as having "unquestionable only one generation in the course of the year, lying almost the whole years as eggs; all ponds in which the species is found are commonly dry from June to March". Also from southern Finland it is reported as vernal species (single emergence) from permanent, polluted pond situated at the edge of a forest (Brummer-Korvenkontio et al. 1971). Schaffner (1998) reports it to be a mountain species in France. Also in Greece the species has been recorded only in Rhodope Mountains up to ca $1150 \mathrm{~m}$ above sea level (Kaiser et al. 2001). Generally, in southern Europe it is restricted to mountains. In Fennoscandia it is an earliest spring species, which hatch before $O_{c}$. communis. In Poland it is also the earliest vernal species - larvae are first to develop in snow-melt pools. Also from Slovakia and from the Czech Republic it is reported as "praevernal species", which larvae were met only in April (Michalkova \& Halgoš 2005, Rettich et al. 2007).

Natvig (1948) states that larvae of Fennoscandian Oc. cataphylla develop in the ponds not overshadowed by trees, or ponds lying on the outskirts of forests. Okróy-Rysop et al. (1991) has met the larvae only in forest pools in Polish coastal region, but not in the field pools. Wojnarowicz (1960), Skierska (1974) and Kowalska-Ulczyńska \& Gilka (2003) observed larvae of the species in ponds of all types: in insolated, partly shaded and completely shaded. According to most authors, larvae clearly prefer partly shaded pools. Wojnarowicz (1960), in his study of mosquitoes of Masurian Lakeland, observed that the most favourable sites for larval development of $O c$. cataphylla are frequently drying up, partly shaded ponds with a layer of decaying leaves or needles at the bottom (i.e. ecotone pools). In such pools the author observed larvae from April to October (interrupted by the periods of drying up the ponds). In the pools which dried up 3 times in the course of the season Wojnarowicz observed 3 emergences of Oc. cataphylla, in those which dried up once - two emergences and in permanent ones - only single emergence in the spring. Last years Polish spring-summer weather is uncongenial for forming such pools in July or August, at least for a period sufficiently long for complete larval development. Harsken et al. (1976) reports that the species 
used to be very abundant in the vicinity of Berlin, but progressive lowering of the level of ground water caused considerable decrease in the number of its breeding sites and the species in 1970-s was not numerous any more. Moreover, they report that larvae of the species were recorded in the flooded area in October 1974. In the Kampinos Forest larvae of Oc. cataphylla usually develop only in March-April, but in 1995 they have bred also in autumn. That year the summer was very hot and dry and heavy rainfalls occurred at the end of August. The storms were so abundant that caused a local flood (Wegner 1999).

Oc. cataphylla overwinters in the egg stage. Females lay eggs onto dry litter in the places, which are expected to fill up with the snow-melt water in spring. Eggs usually develop next spring or later. The studies of Carpenter \& Nielsen (1965) showed that female Oc. cataphylla can undergo even five gonotrophic cycles and lay eggs five times during their lifetime.

Larvae prefer $\mathrm{pH}$ neutral but can breed in slightly acid and slightly alkaline water as well. Wojnarowicz (1960) has found them in the water with $\mathrm{pH}=5.7-7.3$. Brummer-Korvenkontio (1971) and Harksen et al. (1976) give $\mathrm{pH}$ values which are embraced within the data of Wojnarowicz. Larvae of Oc. cataphylla easily tolerate polluted water (Harksen et al. 1976, Brummer-Korvenkontio et al. 1971).

Adult females usually occur for a rather short time - from the end of April till June, occasionally they were recorded also in autumn from the area affected by flood. The species has been recorded in all of study polish towns (Wegner 2008).

Migratory: Females prefer forest habitats but they readily migrate to open areas and fly into farm buildings. Females are troublesome biters outdoors, with maximum biting occurring in May, with peak biting around sunrise and sunset. The study of Downe (1960) suggest that they attack different mammals with no preference.

There is no information about vector competence of the species.

\section{Ochlerotatus (Ochlerotatus) communis (De Geer)}

Oc. communis was first described in Northern Europe in 1776 and has been reported to be holarctic in distribution. Two hundred years later Ellis \& Brust (1973) found that the species represents a complex of cryptic or near-cryptic species - at least in North America. No study on sibling species of $O c$. communis was carried out in Europe. Thus the species must be treated as Oc. communis s.1.

It is an univoltine early spring species common in north Holarctic Region. Oc. communis is one of the commonest species in northern Europe - in Lapland (Dahl et al. 2004) and whole Fennoscandia up to about the $70^{\text {th }}$ degree of latitude in the north (Natvig 1948, BrummerKorvenkontio et al. 1971). In Europe it is rather a woodland species but in mountainous regions of Norway larvae may be found in quite open-lying places (Natwig 1948). In southern Europe it occurs only in mountains (Kaiser et al. 2001, Božičić \& Morović 1987, Merdić 1995, Nicolescu et al. 2003).

In Poland it is the most common early-spring species. It predominates early spring mosquito fauna over the whole area of Poland as well in lowland areas (Tarwid 1952; Skierska 1960, 1965, 1974; Skierska \& Lachmajer 1960; Lukasiak 1965; Wegner 1979, 1982, 2002) as in the mountains (Wegner 1991). The species has been recorded in all of study towns of central Europe (Wegner 2008).

Mosquitoes of the communis group have the ability to lay eggs both with a full and partial intake of blood. The number of eggs is determined by the amount of blood consumed, carbohydrate supplements, the physiological age of the female and several biotic factors. In different years, females are able to undergo 4-8 gonotrophic cycles (Volozina 1961). Thus, adult female of the species can produce up to several hundred eggs, which develop next spring 
or later. Eggs are lied onto dry litter in the places, which are expected to remain under the water in spring. The females choose the oviposition sites very precisely using their very sensitive chemical receptors. The species overwinters in the egg stage.

Larvae breed in cold water in temporary and permanent snow melting pools often together with other snow-melt species i.e. Oc. cataphylla, Oc. punctor, Oc. cantans etc. They breed in pools rich in organic matter with bottom covered with decaying leaves situated in forests and open areas. They prefer acid water but rather keep out of saline and polluted water (Harksen et al. 1976). In early spring they breed in huge numbers and hatch simultaneously.

Habitat drying has an effect on the duration of development of larvae. Chodorowski (1958, 1969) observed a reduced time to metamorphosis in larvae developing in drying pools, but this effect disappeared at high mosquito densities (at high densities survival rate of larvae decreased). The author tested also the ability of $O c$. communis larvae to survive short waterless periods and found that $25 \%$ of larvae and $100 \%$ of pupae survived after 18 hours. He suggested that this ability might be of greater importance for survival than an acceleration of development time by desiccation.

In Poland adult females of the species occur from the end of April till July (rarely till August), but under some weather conditions they can develop twice and emerge in September or even October (Wegner 1999). In Finland the second emergence of Oc. communis is rather usual (Brummer-Korvenkontio et al. 1971, Lumiaho \& Itämies 1981). In northern Europe the ecological amplitude of larvae of Oc. communis is especially wide - larvae were found in many kinds of ponds, in the water with $\mathrm{pH}=5.0-8.5$, but they were seldom found in deep ponds (Lumiaho \& Itämies 1981). Data from Poland and Germany show that in central Europe larvae develop in woodland pools with acid water $\mathrm{pH}=4.5-6.0$ (Wojnarowicz 1960, Skierska 1965, 1974). Harksen et al. (1976) give the values of water $\mathrm{pH}=4.1-6.9$.

Females of Oc. communis rather do not fly out of the forest (Skierska 1965) although sometimes they migrate over moderate distances and fly to the human dwellings and farm houses (Skierska 1974). In woodlands they do not fly above canopy at night - they stay either in mid-canopy or in lower levels (Dąbrowska-Prot 1966).

Females are troublesome biters outdoors, eagerly attack people. Maximum biting occurs in May, with peak biting around sunrise and sunset. They attack mainly mammals but bird biting has been recorded as well (Natvig 1948).

Oc. communis is a principal vector of Inkoo virus (Putkuri et al. 2007). It also transmits Ťahyňa virus.

\section{Ochlerotatus (Ochlerotatus) punctor (Kirby)}

Multivoltine species common in north Holarctic and the most common and widespread species in northern Europe - in Lapland (Dahl et al. 2004) and whole Fennoscandia up to about the $70^{\text {th }}$ degree of latitude in the north (Natvig 1948, Brummer-Korvenkontio et al. 1971, Lumiaho \& Itämies 1981). In central Europe it is one of the plague mosquito species, which co-occur often together with Oc. cantans. Mass emergences of Oc. punctor occur in the spring (the most abundant larvae recorded in May), the summer populations usually are condsiderably less abundant (Mohrig 1964, Harksen et al. 1976). Adult females usually occur to the end of August. The species has been recorded in most of study towns of Europe (Wegner 2008).

Also in Poland Oc. punctor is one of the commonest mosquitoes both in lowlands (Tarwid 1952, Dąbrowska \& Tarwid 1954, Dąbrowska-Prot 1979, Skierska 1960, Skierska \& Lachmajer 1960, Skierska 1974) and mountains (Wegner 1991). It is also common in lakelands (Kowalska-Ulczyńska \& Gilka 2003, Wegner 2009), though Wojnarowicz (1960) has not recorded its larvae in small ponds situated in the vicinity of Mikolajki (Masurian Lakeland). 
Szadziewska \& Okróy-Rysop (1988) during their five-year study found that Oc. punctor used to be one of the most abundant species in the mosquito community observed around Zarnowieckie Lake every second year but it became much less abundant in the study area when the change in water regime (more often floods) and other changes in the habitats occurred. Next study carried out around Żarnowieckie Lake three years later by Wegner Z. et al. (1993) showed that the species was still rare in the area. In Germany it is a common species (Mohrig 1964, Harksen et al. 1976), one of the main elements of spring mosquito plagues. In the Czech Republic and Slovakia Oc. punctor used to be common (Kramař 1958) although less abundant than in Poland or Fennoscandia but nowadays it is absent in many lately prepared checklists of species (Jalili et al. 1999, Michalková \& Halgoš 2005, Rettich et al. 2007).

Minař \& Kramař (1980) qualify it as a boreal species typical of peat moors - widely spread in the hill and mountain forests of the Czech Republic and Slovakia. Similar observations has made Wegner (1991) in Świętokrzyskie Mts. In southern Europe it occurs only in mountains and it is not abundant there (Božičić \& Morović 1987, Kaiser et al. 2001, Nicolescu et al. 2003).

Oc. punctor overwinters in the egg stage. Females lay eggs mainly in dried-up hollows and ditches or above the level of standing water. Eggs can wait for submersion even for several years.

Larvae breed in forests and open areas in different half shaded or insolated bodies of water with bottom covered with decaying leaves or needles or with Sphagnum sp. They prefer swampy semi-permanent pools with acid or neutral water $(\mathrm{pH}=3.0-7.9)$. Mohrig (1964) and Harksen et al. (1976) have observed the larvae of Oc. punctor in $\mathrm{pH}=4.0-7.6$. Nevertheless larvae are most abundant in acid water (Mohrig 1964, Wegner unpubl.). They tolerate salinity also, but avoid polluted water (Harksen et al. 1976). Larvae develop mainly in peat bog ponds and in acid meadows, often in the meadows close to the lake shores.

Adult females of Oc. punctor occur mainly in forests, thus they occupy a similar niche to Oc. cantans as a woodland mosquito, but according to the study of Dabrowska-Prot (1962, 1979) adult females of the species are less sensitive to unfavourable environmental conditions than those of other woodland species. In the study on the mosquito activity during the crepuscular hours Dąbrowska-Prot (1962) found out that among summer species Oc. punctor is the first to become active in the evening. At the same time the species shows high flight activity

In central Europe first adult females of Oc. punctor emerge in April/May. Next emergences may occur till August, thus females stay on the wings from May till October. Peak numbers are recorded in May. In the Czech Republic and Slovakia it is an early spring species (only one emergence) typical of coniferous forest in the mountainous region (Kramar 1958). In Swiętokrzyskie Mts in Poland Wegner (1991) reported Oc. punctor to have only one emergence in May but it predominated forest communities and was abundant till August.

Adult females bite a range of animals including humans - mainly large mammals (bovids) but some bird biting has been recorded (Service 1971b). Biting occurs during the crepuscular hours, mainly outdoors. Females of Oc. punctor attack in forests and open areas as well.

Migratory: Mass migrations of the species from forests to open areas have been observed. Females fly into farm buildings.

Oc. punctor transmits Inkoo and Ťahyňa viruses.

\section{Ochlerotatus (Ochlerotatus) sticticus (Meig.)}

Univoltine species common in lowland great river valleys in Holarctic region (in Europe from south Norway and Sweden (but not from Finland, Latvia and Estonia) to Romania 
(Nicolescu et al. 2003), Balcan Peninsula (Snow \& Ramsdale 1999), Greece (Kaiser et al. 2001), Italy and Spain (Ramsdale \& Snow 1999). The species has been recorded in most of study towns of lowland Europe (Wegner 2008).

Oc. sticticus is typical of alder woods, alluvial forests, open forests, parks and sometimes open areas. It is a late vernal/summer species, which larvae develop in water as the temperature rises with the advancing season. Although larvae of first and second instars relatively well survive in the temperature lower than $15^{\circ} \mathrm{C}$, temperature must rise above this level for later growth. Optimal temperature for development of larvae is $21^{\circ} \mathrm{C}-25^{\circ} \mathrm{C}$, and the full development takes ca 10-12 days (Trpiš \& Horsfall 1969). Therefore in the climate typical of central Europe the first spring development may be possible as early as half of May or June.

Oc. sticticus is one of the flood-water species, which composes mosquito plagues after spring and summer floods or heavy rainfals. Thus its occurrence depends on hydrologic phenomena occurring in the period from half of May, June, July to August (Harksen et al. 1976, Wegner 1979). Mohrig (1964) reports it as a plague summer species (together with Ae. cinereus) from seaside forests near Greifswald. Also in Poland great numbers of the species have been recorded in seaside forests and in the valley of Vistula river (Skierska 1960, Skierska \& Lachmajer 1960, Skierska 1965, Wegner 1979). Huge numbers of females were recorded after the flood, which affected Central Europe in 1997 (Rettich 1998). After summer heavy rainfalls it emerges in Warsaw's parks and housing estates (Wegner, unpubl.). The species may have two or three emergences during the season - from May to September depending on hydrologic conditions (Kramár 1958). In the Czech Republic it has been recorded as a plague mosquito along lower Morava, Dyje and Danube rivers. A mosquito plague, composed mainly of Oc. sticticus, occurred in August 2000 after the flood, which occurred in one of southern parts of Sweden (Lundström et al. 2008). Other years the species also predominated the summer mosquito community but was four to nine-fold less numerous.

In the distance from greater rivers it occurs commonly bur not numerously (Skierska 1965, 1974, Szadziewska \& Okróy-Rysop 1988, Wegner et al. 1993), although Wojnarowicz (1960) has not recorded the species from Masurian Lakeland. In the Swiętokrzyskie Mts. it also has been recorded but only in valleys and not numerously (Wegner 1991).

Like other flood-water species females produce huge numbers of drought-resistant eggs that can stay able to develop for several years. Larval hatching is released by several factors: i.e. decline in dissolved oxygen and water temperature (Gjullin et al. 2005). However, not all larvae hatch at the same time and this phenomenon secure survival to the species in case subsequent larval populations die because of drying of breeding ponds.

The larval development is temperature-dependent and can be completed within a decade or so. The observations by Schäfer \& Lundström (2006) indicated that larvae of Oc. sticticus responded to decreasing water levels by decreasing the time to metamorphosis. However, the authors did not observe it to result in smaller adults (unlike Ae. vexans). Other authors maintained that under unfavourable environmental conditions adults grow very small.

Larvae breed in temporary half shaded pools which form as a result of flood or heavy rainfalls. They prefer forest pools with a bottom covered with decaying leaves with neutral water $\mathrm{pH}=6.8-7.5$ (Mohrig, 1964, Harksen et al. 1976). In central Europe adult females occur from May/June till September, sometimes till October (Michalková \& Halgoš 2005, Wegner 1999). Females are troublesome biters outdoors, with maximum biting occurring in July and August, and peak biting around sunrise and sunset. The species overwinters in the egg stage.

Migratory. Oc. sticticus is known for its long-range dispersal ability. Females have been shown to disperse at least ten kilometers from their breeding sites (Brust 1980). When air humidity is high the females readily fly into open areas and attack during the day.

Oc. sticticus occasionally transmits Ťahyn̆a virus. 


\section{Aedes (Aedes) cinereus Meig.}

Multivoltine species common in Holarctic region. In Europe Ae cinereus is wide-spreaded from south Norway, Sweden and central Finland and other Baltic countries, where it has only one generation during the year (Natvig 1948, Brummer-Korvenkontio et al. 1971) to the southern Europe (Ramsdale \& Snow 1999), where more generations were observed (Kramař 1958, Michalková \& Halgoš 2005, Wojnarowicz 1960).

Minař and Kramár (1980) describe it to be an azonal zoogeographical element, since the species occurs along river valleys in different forest regions - from coniferous forest to deciduous woods and forest-steppe zone. Also in steppe waters the species is very abundant (Dąbrowska-Prot 1979). In Poland Ae. cinereus is common, often very abundant in lowlands (Tarwid 1952, Dąbrowska \& Tarwid 1954, Lukasiak 1959, Skierska \& Lachmajer 1960, Wegner 2002, Kowalska-Ulczyńska \& Gilka 2003). In 1930s and 1950s the species predominated Kampinos Forest summer mosquito fauna. In 1970-s and 1990-s it has been found to occur quite numerously but it was not predominant any more. In autumn of 1995 it occurred in Kampinos Forest in plague numbers (Wegner 1999). Also Skierska (1965) observed the species to predominate mosquito community in the seaside forest near Sztutowo.

In Europe the species is known to occur occasionally in mass numbers. Mohrig (1964) reported it as a plague species from the surroundings of Greifswald, Lukasiak from Świnoujśsie (after Skierska 1974), Jalili et al. (1999) from Morava flood plain. Ae. cinereus has also been recorded in all of study towns of lowland Europe (Wegner 2008).

Ae. cinereus overwinters in an egg stage. Eggs are laid throughout summer time both in dry areas prone to freshwater flooding (i.e. shallow woodland or meadow pools) and in the vicinity of existing deeper pools (i.e. boggy banks of river, flood meadows, border of lakes etc.). The places for egg-laying females choose above the water level and on the grass growing around the pond. Such behaviour allows the species to occur in deeper, permanent ponds (however always in shallow places near the shore), which are rather avoided by other Culicinae species. Wojnarowicz (1960) observed larvae to breed also in a range of temporary, shaded or halfshaded pools in meadows, peat-bogs or in forests - in the temporary early spring pools larvae developed only in May, in other ponds larvae did not occur in May, but they appeared in July after the pond dried up and was refilled again. Wojnarowicz (1960) observed also ponds in which larvae developed in spring, summer and autumn. Thus, the author qualified Ae. cinereus as ubiquitous species. In larger ponds larvae prefer shallow places close to the shore, insolated and covered with terrestrial grass.

Larvae prefer slightly acid or neutral water $\mathrm{pH}$ but have been recorded even in water with $\mathrm{pH}=3.0$. They avoid alkaline water (Harksen et al. 1976). According to Mohrig (1969) the species needs higher temperature than other woodland snow-melt species. Larvae hatch at $12-$ $13^{\circ} \mathrm{C}$, and development starts at $14-15^{\circ} \mathrm{C}$. Optimal temperature for development is $24-25^{\circ} \mathrm{C}$ and the whole process takes then 8 to 10 days.

Female Ae. cinereus repeatedly feed on blood and lay eggs. The maximal number of ovipositions recorded by Shlenova \& Bei-Bienko (1962) for the species was four.

Adult females remain on the wings from May till November. They are abundant in different habitats in open areas, peat bogs, wet meadows, and in forests. They are susceptible to low air humidity and avoid staying in sunlight. Females spend the days in low vegetation and bite at dusk and dawn. Ae. cinereus is known to attack in mass numbers even during the day, but only in overshadowed places (Natvig 1948, Mohrig 1969, Dąbrowska-Prot 1979, Tarwid unpubl.).

In the woodland habitats of Kampinos Forest the species readily spends the night hours in the canopy (Dabrowska-Prot 1966). Although Ae. cinereus seems to be not resistant to low humidity its females occur in different habitats not favourable for mosquitoes (unlike $O C$. 
cantans, which does not occur in such habitats at all). Only its abundance in these habitats depends on environmental factors - less favourable conditions less abundant the species is (Dąbrowska-Prot 1979).

Females feed mainly on mammalian blood (mostly on cattle) and will bite humans readily when available. Ae. cinereus is considered ankle biter because it usually bites the lower extremities. It is a very troublesome biter. Some feeding on birds have been recorded (Service 1971b). As a small-sized species it takes rather small blood-meals, although they are large in relation to females' size (1.33 its mean body weight, while in largest species it is 0.82) (Service 1968).

Ae. cinereus is a competent vector of arboviruses (Ockelbo, Ťahyňa and West Nile).

\section{Aedes (Aedimorphus) vexans (Meig.)}

Multivoltine late spring species with Holarctic distribution, some authors concern it cosmopolitan. In Europe it is spread from southern Fennoscandia through the rest of the continent. Minař and Kramář (1980) describe Ae. vexans to be an azonal zoogeographical element spread along greater rivers from coniferous forest, mixed forest and deciduous forest as well as forest-steppe zone. They include it among forest-steppe elements. Also in steppe environments the species is numerous (Dąbrowska-Prot 1979).

Ae. vexans is a flood-water species typical of valleys of lowland great rivers. It has been recorded in all of study towns of lowland Europe (Wegner 2008).

The species overwinters in the egg stage. In temperate zone diapause lasts from September until March or April of the following year. Females produce huge numbers of drought-resistant eggs, which can survive for at least five years. They lay them into damp depressions or above water level of existing water body. After a single blood-meal, a female can lay more than 100 eggs; occasionally after repeated blood meals it can lay next egg batches (Becker et al. 2003).

Larvae do not hatch when the temperature does not exceed $10^{\circ} \mathrm{C}$ (Gjullin et al. 1950 , Gunstream \& Chew 1964). The hatching rate is particularly high in high water temperature and after the diapause. The larvae hatch within a few hours after flooding, when the water become stagnant and the level of dissolved oxygen decreases (Gjullin et al. 2005). Not all of the larvae hatch just after flooding, but only a proportion of them ("hatching in installments"). It secures the survival of the species in case when one or more larval populations are annihilated by too fast disappearance of breeding sites. If one population of larvae fail to complete the development because its breeding site has dried out, a second population can develop during a following flood even if no additional eggs were laid.

The larval development is temperature-dependent and can be completed within very short time. Optimal temperature for development is $30^{\circ} \mathrm{C}$ and it takes one week to complete. In $15^{\circ} \mathrm{C}$ it takes ca three weeks. Thus, under optimum conditions, Ae vexans needs less than three weeks from hatching of one generation to the next one (water stages: ca six-seven days; mating and host seeking ca four-five days; egg development ca five-six days and embryogenesis ca four-five days) (Becker et al. 2003). According to the observations of Schäfer \& Lundström (2006) the time of development of water forms to adult emergence of Ae. vexans increases under a decreasing water schedule and adult size is reduced. At the same time, they observed that some adults emerged long after water removal ( 6 to 14 days). It seems that larvae and pupae show remarkable survival ability in humid soil.

Larvae of Ae. vexans breed in fresh water pools situated in open areas - in meadows, fields and edges of forests. They prefer neutral water but tolerate slightly acid or slightly alkaline water $(\mathrm{pH}=6.5-7.8)$ (Harksen et al. 1976). Larval densities of the species can be very high of approximately 10000 Ae. vexans larvae per $1000 \mathrm{ml}$ has been observed in inundation areas 
in the Rhone River (Schäfer \& Lundström 2006) as well as ca 5 000-8 000 larvae per $1000 \mathrm{ml}$ in Wilanów (Warsaw) (Wegner unpublished).

Adult females occur from June till November. Huge numbers of females were recorded after the flood, which affected Central Europe in 1997 (Rettich 1998). Adult females are resistant to unfavourable conditions. Dąbrowska-Prot (1979) reported the species to colonize inhospitable terrain fairly effectively and evenly. She pointed out that females coped with unfavourable environmental conditions by means of modifications in their behaviour.

Migratory. Adults fly from their breeding sites to scrubs, woods and forests. They can also migrate over long distances to find a host for the blood-meal - according to the weather conditions the flight capacity is about $\mathrm{lkm} /$ night. Migrations of $12 \mathrm{~km}$ were proved by Brust (1980) while those of 18 to $50 \mathrm{~km}$ were reported as common occurrences by Stage et al. (1937). Horsfall (1954) reports huge displacement of Ae. vexans for 90 to 260 miles probably with a massive cold air front within 48 hours. It is evident that only a part of the emigrated population returns to the original breeding sites after the blood-meal, while a considerable part of the population do not return and lay eggs far away from their original breeding sites. Therefore the migration leads to a natural regulation of the population densities on one hand and to spread of the species on the other.

Fertilized females rarely fly into human houses and farm buildings. Nevertheless, the immigration of females into human settlements, e.g. gardens and parks, can cause of considerable nuisance, since Ae. vexans is a very troublesome bitter outdoors, with maximum biting occurring in July and August, with peak biting around sunrise and sunset, but it bites also during a day. Several authors showed that Ae. vexans is a primarily mammalophilic mosquito but sometimes it feeds on birds. Molaei \& Andreadis (2006) found that ca 7\% of blood-meals acquired by Ae. vexans were of avian or mixed avian and mammalian origin.

The species is known as an efficient vector of dog's filariosis. It is a main transmitter of Ťahyňa, West Nile and Batai viruses. Molaei \& Andreadis (2006) recognized the potential of the species as a bridge vector of West Nile Virus. The data of Tiawsirisup et al. (2008) indicate that Ae. vexans can be an efficient enzootic WNV vector - compared with $C x$ pipiens (the main vector of $\mathrm{WNV}$ ) it can be considered a moderately to highly effective WNV vector.

\section{Culex (Culex) pipiens L. forms : pipiens L. and molestus Forskäl}

Cosmopolitan multivoltine and synathropic species. Most common species in all of study towns of Europe (Wegner 2008).

$C_{X}$. pipiens occurs in two physiological forms: the pipiens and the molestus, collectively referred to as $C_{X}$. pipiens s.l. They are indistinguishable in terms of morphology but they differ in feeding habits and breeding sites. Females of the pipiens form are believed to be almost exclusively ornithophagic (bird biting) and rarely bit humans - evidence given by several authors, i.e. Apperson et al. (2002) in their study in New York showed that the large majority of blood-meals (97\%) taken by $C_{X}$. pipiens pipiens were from avian hosts and only a few (ca $3 \%$ ) from mammals. The pipiens form of the species does not bite people.

Adult females are active during the warmer months. They have been met in natural habitats open and forest ones, in rodent's burrows, cellars, aboveground buildings, even in flats on the fourth floor (Lukasiak 1965). Adult females hibernate in cool buildings or in natural caves, as well as in animal burrows, tree holes etc. $C_{X}$. pipiens form pipiens mates and breeds in open spaces. Females require blood for the development of eggs. After a full blood-meal they can take another portion of blood during the same gonotrophic cycle. When a female can not have a full blood portion at once, it, as a rule, takes another one and the next portion of blood if needed. The full blood-meal (twice as heavy as the body weight) is enough to produce 200-250 
eggs. Fecundity depends on body weight (small females can lay ca 195 eggs, the largest ones260) and on the host species i.e. after human blood-meal the fecundity is ca 50\% lower than after bird's blood (Vinogradova 1997). Larvae breed in different natural and artificial aboveground water bodies, such as ponds, marshes, backwaters in streams, hoof prints, pools, ditches, tree holes and containers such as tanks and butts. It does not make a difference for the species if the water is clean or foul, with or without emergent or overhanging vegetation. Larvae of the species have been recorded in brackish water as well as in heavy polluted poolseven in sewage settling ponds. Natvig (1948) reports larvae from dunghills, Rydzanicz \& Lonc (2003) from aboveground system of communal sewage settling ditches in Wroclaw. Depending on climate it can breed 3-4 generations in Fennoscandia (Natvig 1948), 4-5 generations in central Europe (Mohrig 1969) or even more in the southern Europe where $C_{X}$. pipiens larvae were observed from April/May till November) (Marshall 1938, Aldemür \& Boşgelmez 2006).

In typical weather conditions of central Europe one gonotrophic cycle takes 15 days. The development of eggs take $65-74$ hours in $28-29^{\circ} \mathrm{C}$ to $84-92$ hours in $22-25^{\circ} \mathrm{C}$ after the bloodmeal. The development of water stages lasts 24 days in $18.5^{\circ} \mathrm{C}, 17$ days in $21.9^{\circ} \mathrm{C}, 10$ days in 25 and 9 days in 26-27 (Vinogradova 1997). In central Europe the females of $C_{X}$. pipiens stay on wings from May till October. In summer months females keep away from human dwellings (Dąbrowska-Prot 1979).

In woodland, during the night they penetrate the tree crowns and most eagerly fly above canopy unlike other species which do not fly so high (Dąbrowska-Prot 1966).

In the end of August and in September they need to gather food resources to survive overwintering. Then they seek for a favourable place for hibernation and become more visible since they fly to human settlements. Spielman \& Wong (1973) found that $C_{X}$. pipiens females commonly enter diapause after depositing one or more clutches of eggs. It is accepted that short daylength initiates hibernation in $C_{X}$. pipiens pipiens (Danilevskii \& Glinyanaya 1958, Vinogradova 1960) (but not in CX. pipiens molestus) and that prior to hibernation blood feeding stops and fat reserves are accumulated by feeding on plant secretions (Service 1968). Tarwid (1952) and Dąbrowska-Prot (1979) observed mass migrations of female $C_{X}$. pipiens to moorlands where they fed on heath bells (Calluna vulgaris) and Skierska (1965) observed huge numbers of females feeding on plants in the Baltic coastal forest belt, close to the shore in autumn 1960

Cx. pipiens form molestus. Earlier the name "molestus" has been used as the name of a species. Both forms were referred to be separate species. Now, the name "molestus" is widely applied to $C_{X}$. pipiens populations, which exhibit autogeny and mammalophilic feeding preferences-they are behavioural/physiological variants of $C_{X}$. pipiens that have evolved independently in specialized habitats (Apperson et al. 2002). Formally, the name "molestus" is a junior synonym of $C_{X}$. pipiens and should not be used as a subspecific name (Harbach et al. 1984).

Females of the molestus form are active in buildings through winter, normally breeding in underground water, including flooded basements, cisterns and tanks in buildings, sumps at the bottom of lift shafts, leakage pools in heated cellars and boiler rooms, often in the permanent darkness. The molestus form breeds in confined spaces and exhibits autogeny (ability to produce eggs without blood). The permanent populations may exist whole year round only in heated basements flooded by sewage or mixed waters with high organic pollution and temperatures within $10-34^{\circ} \mathrm{C}$. Thus they do not enter winter diapause. The rate of autogeny usually is rather high. $80-100 \%$ of females oviposit the first egg batch without blood-feeding (Vinogradova 1997). This provides the existence of autonomous local populations over a long period. 
Females bite humans and are very aggressive to man, thus the emergence of great numbers of this species may cause a serious problem in hospitals, underground system and so on. Biting by the molestus form generally occurs year-round. It attacks humans viciously and persistently mainly in late autumn and winter, whereas the pipiens form is active between May-October.

Vinogradova (1997) monitored local CX. pipiens populations of the urban mosquitoes in St. Petersburg and showed that the mean size and the mean fecundity differ both between and within local populations varying from 3.1 to $5.4 \mathrm{~mm}$ (wing length) and from 32.9 to 105.7 eggs per female, respectively. She has found a significant positive correlation between autogeny rate and fecundity, and the size of females, while the size is affected by the temperature and pollution of basement waters during the larval development of mosquitoes.

$C_{X}$. pipiens s.1. is a species which breeds to plague numbers in flooded towns. After a flood episode in Gdansk in 2001 the species predominated other mosquito species for several years (Kubica-Biernat et al. 2007).

$C X$. pipiens is a known competent vector of arboviruses: Ťahyňa and West Nile, incriminated of the spread of West Nile epidemic in USA and in temperate Europe. It has also been found to be a vector of dog's filariosis (Cancrini et al. 2006).

\section{Culiseta (Culiseta) annulata (Schrank)}

One of the largest mosquitoes in Poland. Multivoltine species widely distributed in Western Palaearctic Region - throughout western and central Europe, Scandinavia, Russia (east to Petersburg region, north to Estonia, and the Caucasus and Transcaucasian mountains), Middle Asia, the Mediterranean and North Africa and southwest Asia. The species is common in Europe and in the whole area of Poland - Cs. annulata is one of the most common species, but not very abundant. In Poland first recorded by Nowicki (1873) from surroundings of Cracovia.

In Central Europe it occurs up to the elevation $1000 \mathrm{~m}$ above sea level (Kramař 1958), in Southern Europe up to $1500 \mathrm{~m}$ above sea level (Božičić \& Morović 1987). In Finland Cs. annulata was met rarely (Brummer-Korvenkontio et al. 1971), in Northern Norway it is also rather rare species and it breeds only one generation during a growing season, in South Norway and Sweden it is more common and breeds two or three generations (Natwig 1948); in Great Britain, Poland, Germany, the Czech Republic and Slovakia it is common and breeds three or even four generations per year (Kramař 1958, Marshall 1938, Mohrig 1964, Skierska 1974).

In Central Europe larvae usually were observed from May to October, although in England and Germany during mild winters, when the temperature in February and March is relatively high, larvae have been met as early as March (Harksen et al. 1976). In Southern Europe Cs. annulata breeds all the year round (larvae were observed even during the winter) (Marshall 1938, Aldemür \& Boşgelmez 2006).

It is accepted that larvae of $C$. annulata breed in a broad spectrum of sites in natural and artificial waters in sunlit or shaded areas but it seems that in the Forest Zone they prefer shaded pools since Eukasiak (1965), Mohrig (1964), Okróy-Rysop et al. (1991) observed larvae of the species only in shaded pools. Skierska (1974), on the basis of her observations carried out in different regions of Polish Baltic Seaside, concluded that, although larvae occurred in all of examined water habitats (meadow, forest, lake shores), they preferred ecotones between forest and meadow or between a lakeshore and a forest. In Northern countries they were met also in insolated pools (Natvig 1948).

The larvae were met in fresh or brackish, clean or polluted water. They live in different bodies of water including ponds, ditches, marshes, garden water butts and cisterns. Females for oviposition choose pools with the muddy bottom covered with decaying matter. Marshall (1938) points out that "it seems that water contaminated by nitrogenous matter provides an 
additional attraction since tanks containing manure waters employed for gardening purposes", also water heavy polluted with urine was reported to be infested with larvae of Cs. annulata (Wesenberg-Lund 1921). The author observed them also in a pond covered with Lemna sp. Larvae of the species were often met numerously (together with $C_{X}$. pipiens) in aboveground sewage system in Wroclaw. They have been observed in those heavy polluted water every month from April to September, but most numerously in July and August (Rydzanicz \& Lonc 2003). Larvae prefer neutral water although they were reported from both acid and alkaline waters $(\mathrm{pH}=4.1-8.5)$. They also tolerate a wide range of salinity (up to $2000 \mathrm{mg} \mathrm{Cl} / \mathrm{l}$ ) (Mohrig 1964, Harksen et al.1976, Rydzanicz \& Lonc 2003).

The species is believed to be an element of synanthropic fauna. It has also been recorded in all of study towns of Europe (Wegner 2008), although Skierska (1974) maintain that in the Baltic coast Cs. annulata is most numerous in relatively sparsely populated and uncultivated areas (wastelands) lying close to the lakes, which adjoin large forest complexes.

Roiz et al. (2007) and Hatherly et al. (2009) report larvae of Cs. annulata breeding in used tires, thus the species can be transported all over the world with the tyres, like Asian Tiger mosquito Aedes albopictus. From a time there are reports of the presence of $C_{S}$. annulata in the Western Hemisphaere (Faran \& Bailey 1980).

In Poland adult Cs. annulata leave hibernation sites in April, then feed and lay eggs. Engorged females were observed in nature as well as in stables and cowsheds from May to the end of November. They stay on wings in nature even in low temperature - Skierska (1965) has caught female and male of Cs. annulata on plants in the forest on November $30^{\text {th }}$, the air temperature being $6^{\circ} \mathrm{C}$.

Adult females feed both indoors and outdoors on a variety of hosts including mammals and birds. They eagerly bit humans if available. Reports of mosquito biting in late autumn or early spring are very often attributed to this species, since the bites of $C s$. annulata are painful and cause high allergic response.

Cs. annulata overwinters as fertilized female thus adult females fly into cellars and human dwellings in autumn. They spend the winter months both in natural habitats (caves, animal burrows, tree holes etc) and in man made ones: underground buildings (cellars etc) and in farm buildings, sheds, attics together with $A n$. maculipennis and $C_{x}$. pipiens. Unlike these species $C$ s. annulata takes blood-meals both before and at intervals during hibernation (Marshall 1938).

Blood digestion rate depends on temperature. Service (1968) observed that the digestion of blood portion took 10-31 days in hibernating females. It seems that females feed 4-5 times during hibernation and some of them may complete at least one gonotrophic cycle and lay eggs during the winter - Service (1968) reports the presence of egg rafts of Cs. annulata in December and January. Also Lukasiak (1965) observed females ovipositing in January or February. The mean egg batch of a female Service (1968) found to be 150 (range from 78 to 343), which is consistent with data of Marshall (1938) who gives 343 eggs as a value of maximum batch.

The species is competent vector of arboviruses (Ťahyn̆a, West Nile) as well as of the avian malaria parasite and avian pox virus. Transovarian transmission of viruses has been proved Bardos et al. (1978) isolated the Ťahyňa virus from a pool of first generation, field collected, Cs. annulata larvae from Moravia, Czech Republic.

\section{Coquillettidia (Coquillettidia) richiardii (Ficalbi, 1889)}

Univoltine species distributed in Palaearctic Region. Its distribution spreads thorough a whole Europe, the Near East, Central Asia, Kazakhstan, South Siberia to the east up to the river Yenisey. In Siberia the species is typical of steppe zone, it is less abundant in forest-steppe 
although locally it can often occur in mass numbers. In taiga it is much less numerous (Kukhartchuk 1980).

In Europe Cq. richiardii is common in lowlands, especially along great rivers (i.e. lower Danube), and lakelands. It is also common in the whole area of lowland Poland. Locally, the species can be the most numerous species in the community (Dąbrowska-Prot 1979) or even breed to the plague numbers (Peus 1950, Kowalska-Ulczyńska \& Gilka 2003).

The larvae develop in permanent pools in different way than other mosquito species, which larvae live free in the water and need to go to the water surface to breathe with atmospheric air. Larvae of $C q$. richiardii penetrate the aerial system of submerged aquatic plants and live fixed with their modified siphons to their roots. They prefer emergent aquatic macrophytes, such as Ranunculus sp., Acorus sp., Glyceria sp., Typha sp. Gozhenko (1978) found abundant larvae on the roots of Typha augustifolia, less larvae of Scirpus lacustris and Hydrocharius morsus ranae and only a few in the roots of Spirodella polyrrhiza, Lemna trisulca and Salvinia natans. No larvae were found on Phragmites communis. Being fixed to the plant the larvae of $C q$. richiardii take their food from the surrounding water by means of filtering.

The invasive potential of the species depends both on the migratory ability of adult females and on the mode of life of its larvae - being sedentary they are almost completely invisible for predators.

The main factors influencing larval attachment seem to be the light (they avoid light) and oxygen concentration - more favourable for them is a dark anoxic environment. Carbon dioxide produced by the root system of the host plant seems to be an attractive cue for larval attachment. Also certain number of commonly found, highly water-soluble, low-molecularweight compounds, several of which (glycerol, uracil, thymine, uridine, thymidine) induce attraction for larvae. These compounds appear to act synergistically, since a mixture of these five compounds attract larvae at natural concentrations much stronger than those found for each compound tested individually (Sérandour et al. 2008).

Almost a year elapses between oviposition and adult emergence (Guille 1976). Cq. richiardii overwinters as larvae of $3^{\text {rd }}$ and $4^{\text {th }}$ stages. When the winter is hard and frosty larval survival is low. First pupation occurs in May. Also pupae live fixed with trumpets to the aerial system of emergent plants. When the time of eclosion comes the joint breaks down and pupa emerges from the water to the surface where adult individual appears (Gutsevich et al. 1971).

In temperate Europe the newly emerged adults appear in June and become numerous in July and in August they disappear. Similar phenology has been observed in Siberian steppes, while Russian researches in southern forest-steppe zone observed adults from the middle of May to August and three peaks of occurrence: the end of June, middle of July and the end of July (Kukhartchuk 1980). Russian authors (Gutsevich et al. 1971) maintain that the species breeds one generation in northern regions of its range to three generations in the southern.

Adult females are very aggressive to humans and animals but they are on the wing when it is dark and their attacks may pass unnoticeably. They may enter houses to feed but leave again before dawn. Mass attacks occur after sunset, peaking between 22.00-24.00h.

Service (1968) showed significant positive correlation between the size of unfed females and the quantity of blood ingested and no correlation between the size of blood meal and number of eggs laid by a female of $C q$. richiardii.

Migratory: females can fly over long distances.

Cq. richiardii is a competent vector of Thahyňa and West Nile viruses. It is also a possible vector of dog's filariosis, since filarial DNA has been found in examined females but to confirm its vector competence further study is necessary (Cancrini et al. 2006). 


\section{ANALYSIS OF POLISH FAUNA}

A number of species of Polish mosquito fauna (ca 53.2\%) are univoltine (Table I). They breed only one generation during growing season. It does not mean that larvae develop only within short period and adults emerge simultaneously. This refers mainly to early spring species, which breed in snow-melt pools. Only two of these snow-melt species - Oc. communis and Oc. cataphylla, which can breed to huge numbers were categorized to be most troublesome Polish mosquitoes. Ca $47 \%$ species of Polish mosquitoes are multivoltine and they account for almost 60\% within the group of most troublesome Polish mosquitoes. They breed more than one generation during growing season. Adult females of these species occur for several months - some of them from May to September or even till November. At least three univoltine species can emerge more than twice per year. Their occurrence can be prolonged to several months - similar to that in multivoltine species. Within a category of most troublesome mosquitoes in Poland the species, which have two or more emergences during a season (both univoltine and multivoltine) account for 75 per cent while in the whole Polish fauna they make 53 per cent. Such a difference is significant.

A female of some multivoltine species can produce even several thousand eggs, which can survive desiccation and stay able to development for several years. They lay them into water or on dry litter in the depressions of the ground, which are expected to fill up after a heavy rainfall or flood. If there is a hot and wet season the turnover of generations is fast and the plaque of mosquitoes become a real danger. The situation usually takes place in summer because the speed of egg development in ovaries and the rate of growth of larvae depend on temperature. Thus the development of early spring species, which breed in cold water takes 8-12 weeks while summer species under favourable circumstances can complete their development in 7-10 days.

Table 1. Characteristics of most troublesome mosquito species compared with all species of Polish Culicidae.

\begin{tabular}{|l|c|c|}
\hline \multicolumn{1}{|c|}{ Species } & $\begin{array}{c}\text { Proportion of the group in all } \\
\text { Polish mosquito species }\end{array}$ & $\begin{array}{c}\text { Proportion of the group within a } \\
\text { category of most troublesome } \\
\text { mosquito species }\end{array}$ \\
\hline $\begin{array}{l}\text { Univoltine } \\
\text { Multivoltine }\end{array}$ & 25 species $=53.2 \%$ & 5 species $=41.7 \%$ \\
Having two or more emergences/season & 22 species $=46.8 \%$ & 7 species $=58.3 \%$ \\
Having a broad spectrum of ecological & 25 species $=53.2 \%$ & 9 species $=75.0 \%$ \\
tolerance of larvae (eurytopic species) & 20 species $=42.6 \%$ & 7 species $=58.3 \%$ \\
$\begin{array}{l}\text { Having a narrow spectrum of ecological } \\
\text { tolerance of larvae (stenotopic sp.) } \\
\text { can breed in artificial ponds }\end{array}$ & 27 species $=57.4 \%$ & 5 species $=41.7 \%$ \\
$\begin{array}{l}\text { Migatory (more or less) } \\
\text { Competent vectors of human diseases }\end{array}$ & 2 species $=4.3 \%$ & 2 species $=16.7 \%$ \\
\hline
\end{tabular}

Ae. cinereus, Ae. vexans and Oc. sticticus are well known as plague species typical of the valleys of great rivers. They often follow flood disasters. Larvae of flood-water species - Ae. vexans and $O c$. sticticus, which are the main components of mosquito plagues are rather stenotopic - they need neutral water $\mathrm{pH}$ and do not tolerate salinity and pollution. Another species $-C_{X}$. pipiens, which larvae show a wide spectrum of tolerance, breeds to mass numbers in flooded towns where Ae, vexans and Oc. sticticus are much less abundant. A broad spectrum of ecological tolerance of larvae does not seem to be a very important attribute of most troublesome species while the migratory abilities does. In the category of most troublesome mosquitoes the percentage of migratory species account for over 2.5 fold more than that in the whole Polish fauna (Table 1). 
A huge majority of troublesome species show vector competence - eleven of these twelve species are competent vectors of human diseases (which accounts for 91.7 per cent) while in the whole Polish fauna there are 20 species which are competent transmitters $(42.6 \%)$. The difference is significant even if one takes into account that a vector competence is studied mainly in these species, which occur in large numbers.

Summing up, there are some attributes which plague mosquitoes have in common: the ability to breed more than one emergence per year, the migratory ability and vector competence while wide spectrum of ecological plasticity of larvae seems to be less important factor.

\section{REFERENCES}

ALdeMür A., BoşGelmez A. 2006. Population Dynamics of Adults and Immature Stages of Mosquitoes (Diptera:Culicidae) in Golbaşi District, Ankara*. Turkish Journal of Zoology 30: 9-17.

Apperson C. S., Harrison B. A., UnNasch T. R., HASSAN K. H., IRBY W. S., SAVAGE H. M., Aspen S. E., WATSON D. W., Rueda L. M., ENgBer B. R. \& NAsci R. S. 2002. Host-Feeding habits of Culex and Other Mosquitoes (Diptera, Culicidae) in the Borough of Queens in New York City, with Characters and Techniques for Identification of Culex Mosquitoes. Journal of Medical Entomology 39: 777-785.

BARDOS V., RYBA J., HUBALEK Z. \& OLEJNICEK, J. 1978. Virological examination of mosquito larvae from southern Moravia. Folia Parasitologica (Prague) 25:75-78.

Becker N., Petric D., Boase C., Zgomba M., Lane J., Dahl C. \& Kaiser A. 2003. Mosquitoes and Their Control. Kluwer Academic/Plenum Publishers, New York, Boston, Dordrecht, London, Moscow, xxi+498 pp.

BoŽIĆIĆ B. \& MORović M. 1987. The fauna of Durmitor, 2: Culicidae (Insecta, Diptera) - Crnogorska Akademija Nauka i Umjetnosti, Titograd. Knjiga 21, Odjeljenje prirodnih nauka, Knjiga 13: 177-200.

BRTMMER-KORVENKONTIO M., KORHONEN P. \& HÄMEEN-ANTTILA R. 1971. Ecology and phenology of mosquitoes (Dipt., Culicidae) inhabiting small pools in Finland. Acta Entomologica Fennica 28: 51-73.

BRUST R. A. 1980. Dispersal behaviour of adult Aedes sticticus and Aedes vexans (Diptera: Culicidae) in Manitoba. Canadian Entomologist 112: 31-42.

Buckley A., Dawson A., Moss S. R., Hinsley S. A., Bellamy P. A. \& Gould E. A. 2003: Serological evidence of West Nile virus, Usutu virus and Sindbis virus infection of birds in the UK. Journal of General Virology 84: 2807-2817.

Cancrini G., Magi M., Gabrielli S., Arispici M., Tolari F., Dell'omodarme M. \& Prati M. C. 2006. Natural vectors of dirofilariasis in rural and urban areas of the Tuscan region, Central Italy. Journal of Medical Entomology 43: 574-579.

CARPENTER, S. J. \& NELSEN, L. T. 1965. Ovarian cycles and longevity in some univoltine Aedes species in the Rocky Mountains of western United States. Mosquito News 25: 127-134.

CHODOROWSKI A. 1958. Influence of the drying-up of temporarily-formed pools on the rate of development of mosquito larvae of the Aedes genus. Ekologia Polska Ser. B 4: 35-39. [In Polish].

CHODOROWSKi A. 1969. The desiccation of ephemeral pools and the rate of development of Aedes communis larvae. Polskie Archiwum Hydrobiologii 16: 79-91.

DANILEVSKIY A. S. \& GLINYANAYA E. I. 1958. The dependence of the gonotrophic cycle and imaginal diapause of blood-sucking mosquitoes on variation in day-length. In: DANILEVSKIY A. S (ed.), The Ecology of Insects, pp. 34 51. Uchenye Zapisky Leningradskovo Ordena Lenina Gosudarstviennovo Universiteta, Series of Biological Sciences No. 240, Leningrad, $160 \mathrm{pp}$.

DAHL C., NIELSEN L. T. \& PETERSSON E. 2004. Mosquito larvae (Diptera: Culicidae) in snow-melt pools in a Swedish Lapland Area. Journal of Vector Ecology 29: 109-123.

DABROWSKA E. \& TARWID K. 1954. Remarks on the occurrence of forest mosquito associations in the Kampinos Forest. Ekologia Polska 2: 203-214. [In Polish with English summary].

DABROWSKA-PROT E. 1962. Reactions of some mosquito species to microclimatic factors. Bulletin of the Polish Academy of Sciences 10: 531-535.

DABROWSKA-PROT E. 1966. Changes of the vertical distribution of mosquitoes in forest environment. Ekologia Polska. Ser. A 14: 635-650.

DABRowSKA-PROT E. 1979. Mosquitoes - the components of aquatic and terrestrial ecosystems. Polish ecological Studies 5: $5-88$.

DE JONG R. \& KNOLS B. G. J. 1995. Selection of biting sites on man by two malaria mosquito species. Experientia 51: $80-84$.

DownE, A. E. R. 1960. Blood-meal sources and notes on host preferences of some Aedes mosquitoes (Diptera: Culicidae). Canadian Journal of Zoology. 38: 689-699. 
ELLIS R. A. \& BRUST R. A. 1973. Sibling species delimination in the Aedes communis (De Geer) aggregate (Diptera: Culicidae). Canadian Journal of Zoology 51: 915-959.

EDWARDS F. W. 1932. Genera insectorum. Diptera. Fam. Culicidae. Fasc. 194. Desmet-Verteneuil, Brussels, 258 pp.

FARAN M. E. \& BAILEY C. L. 1980. Discovery of overwintering adult female of Culiseta annulata in Baltimore. Mosquito News 40: 284-287.

GJUlin C. M., Yates W. W. \& Stage H. H. 1950. Studies on Aedes vexans (Meig.) and Aedes sticticus (Meig.), flood-water mosquitoes, in the lower Columbia River Valley. Annals of the Entomological Society of America 43: 262-275.

GJULIIN C. M., HEGARTy C. P. \& BOLLEN W. B.. 2005. The necessity of a low oxygen concentration for the hatching of Aedes mosquito eggs. Journal of Cellular Physiology 17: 193-202.

Gurlle G. 1976. Recherches éco-étthologque sur Coquillettidia (Coquillettidia) richiardii (Ficalbi) 1889 (Diptera Culicidae) du litoral méditeranéen français. II. Milieu et component. Annales des Sciences Naturelles (Zoologie) 18: 5-112.

GozHENKo V. A. 1978. Biotopes and times of development of Mansonia richiardii (Ficalbi) 1889 in the conditions of Ukrainian steppes. Meditsinskaia Parazitologiia i Parazitarnye Bolezni 47: 36-40.

Gunstream S. E. \& CHEw R. M. 1964. Contribution to the Ecology of Aedes vexans (Diptera: Culicidae) in the Coachella Valley, California. Annals of the Entomological Society of America 57: 383-387.

Gutsevich A. V., Monchadskil A. S. \& SHTAKELBERG A. A. 1971. Fauna of the U.S.S.R. Diptera Volume 3, No. 4. Mosquitoes - Family Culicidae. Academy of Sciences USSR, Zoological Institute, New Series No. 100, $408 \mathrm{pp}$ [In Russian].

HARBACH R. E., HARRISON B. A. \& GAD A. M. 1984. Culex (Culex) molestus Forskäl (Diptera: Culicidae): neotype designation, description, variation, and taxonomic status. Proceedings of the Entomological Society of Washington 86: 521-542.

HARBACH R. E. \& HOWARD T. M. 2007. Index of currently recognized mosquito species (Diptera: Culicidae) European Mosquito Bulletin 23: 1-66.

HARKSEN E., MÖNKE R. \& SCHUMANN H. 1976. Faunistisch-okologische Untersuchungen zur Stechmuckenfauna Berlins. Deutsche Entomologische Zeitschrift, N. F. 23: 367-406.

HATHERLy I. S., DOLMAN A. M \& ANDERSON M. 2009. Mosquito breeding in tyre disposal sites in the West Midlands region of the UK. Journal of Environmental Health Research 9: 7-16.

HeRMANOWSKA-SzPAKOWICZ T., GRYGORCZUK S., KONDRUSIK M., ZAJKOWSKA J. \& PANCEWICZ S. 2006. Infections caused by West Nile Virus. Przegląd Epidemiologiczny 60: 93-98.

HoRsFall W. R. 1954. A migration of Aedes vexans Meigen. Journal of Economic Entomology 47: 544.

HuBÁleK Z. \& HALOUZKa J. 1996. Arthropod-borne viruses of vertebrates in Europe. Acta Scientarum Naturalium. Brno 30 (4-5): 95 pp.

HUBÁLEK Z., HALOUZKA J. 1999. West Nile Fever - a reemerging mosquito-borne viral disease in europe. Emerging Infectious Diseases 5: 643-650.

HuBÁLek Z., HALOUZKa J. \& Jứicová Z. 1999. West Nile Fever in Czechland. Emerging Infectious Diseases 5 : $594-595$

Hubálek Z., Savage H. M, Halouzka J., JuŘicová Z., SANogo Y. O. \& Lusk S. 2000. West Nile virus investigations in South Moravia, Czechland. Viral Immunology 13: 427-433.

Hubálek Z., HalouzKa J., JuŘicová Z., Šikutová S., Rudolf I., Honza M., Janková J., Chytil J., MaReC F. \&, SITKO J. 2008a. Serologic survey of birds for West Nile Flavivirus in Southern Moravia (Czech Republic). Vector-Borne and Zoonotic Diseases 8: 659-666.

Hubálek Z., Wegner E., Halouzka J., Tryjanowski P., JERZak L., ŠIKuTová S., Rudolf I., KRUszewiCZ A. G., JAWORSKI Z. \& WEODARCZYK R. 2008b. Serologic survey of potential vertebrate hosts for West Nile virus (Flaviviridae) in Poland. Viral Immunology 21: 247-254.

JALiL. N., HALGOŠ J., ONDRISKA F. \& BRESTOVSKY J. 1999. Mosquito communities of the Morava flood plain area during floods in 1997. Dipterologica bohemoslovaca 9: 77-81.

Kaiser A., Jerrentrup H., SAmanidou-Voyadjoglou A. \& Becker N. 2001. Conrtibution to the distribution of European mosquitoes (Diptera: Culicidae): four new country records from northern Greece. European Mosquito Bulletin 10: 9-20.

KARCZEWSKI B. \& KRZEMIŃSKI J. K.1965. Investigations on the biting mosquitoes (Diptera: Culicidae) in the Park Palacowy in Jablonna near Warszawa. Fragmenta Faunistica 12: 153-163.

KOWALSKA-UlCZyńsKa B. \& GÆKA W. 2003. Mosquitoes (Diptera: Culicidae) of a village Wyskok in Masurian Lowland. Wiadomości Entomologiczne 22: 91-100. [In Polish with English abstract].

KRAMÁR̆ J. 1958. Fauna ČSR. Svazek 13. Komáři bodaví - Culicinae. Praha. 286 pp.

Kubica-Biernat B. 2005. Malaria and its vectors in Poland. In: Buczek A., Blaszak Cz. (eds), Stawonogi Różnorodność form i oddziaływań, pp. 281-287. Koliber, Lublin, 374 pp. [In Polish with English abstract].

KUBICA-BIERNAT B. \& KOWALSKA-ULCZYNSKA B. 2006. Mosquito fauna (Diptera: Culicidae) of the Vistula Spit. In: A. BUCZEK, Cz. BŁASZAK (eds), Stawonogi. Znaczenie epidemiologiczne, pp. 145-151. Koliber, Lublin, 345 pp. [In Polish with English abstract] 
Kubica-Biernat B., Kowalska-UlczyńsKa B. \& STAŃcZaK J. 2007: Mosquito fauna (Diptera: Culicidae) of the Gdansk Agglomeration. In: BUCZEK A. \& BLASZAK Cz. (eds), Stawonogi. Środowisko, patogeny i żywiciele, pp. 61-66. Koliber, Lublin, 361 pp. [In Polish with English abstract].

KuKHARTCHUK L. P. 1980. Blood sucking mosquitoes (Diptera, Culicidae) of Siberia. Nauka, Novosibirsk, 223 pp. [In Russian]

LABUDA M., KOŽUCH O. \& GREŠínOVÁ M. 1974. Isolation of West Nile virus from Aedes cantans mosquitoes in West Slovakia. Acta Virologica 18: 429-433.

Linke S., Niedrig M., Kaiser A., Ellerbrok H., Müller K., Müller T., ConRaths F. J., MÜHLe R. U., SCHMdDT D., KÖPPEN U., BAIRLEIN F., BERTHOLD P. \& PAULI G. 2007. Serologic evidence of West Nile virus infections in wild birds captured in Germany. American Journal of Tropical Medicine and Hygiene 77: 358-364.

LUMIAHO I. \& ITÄMIES J. 1981. On the phenology and ecology of mosquito larvae (Diptera, Culicidae) at Vihanti, central Finland. Annales Entomologici Fennici 47: 1-10.

LUNDSTRÖM J., SCHÄFER M. \& PETERSSON E. 2008. Comparisons of mosquito population by wetland type and year in the lower River Dalälven region, Central Sweden. Journal of Vector Ecology 33: 150-157.

LUKASIAK J. 1965. The studies of the occurrence of Culicinae (Diptera, Culicidae) in Warszawa and its surroundings. Fragmenta Faunistica 12: 1-13.

LUKASIAK J. 1959. Appearance of stinging gnats in the eastern part of Kampinos Wilderness. Acta Parasitologica Polonica, 7: 307-314. [In Polish with English abstract].

Marshall J. F. 1938. The British Mosquitoes. London, Natural History Museum, 341 pp.

MARTINI E. 1931. Culicidae. In: LINDNER: Die Fliegen der Palaearktischen Region. E. Schweizerbart'sche Verlagsbuchhandlung, Stuttgart. $398 \mathrm{pp}$.

MERDIĆ E. 1995. Vertical distribution of the mosquitoes (Dipt., Culicidae) in the mountain of Papuk, Croatia. Entomologia Croatica 1: 25-33.

Michalková V. \& Halgoš J. 2005. Phenology of the mosquitoes (Diptera: Culicidae) in the Morava River Flood Plain. Dipteron: 21: 13-15.

MNÁ̌̆ J. \& KRAMÁR̆ J. 1980. Faunistics and zoogeography of mosquitoes (Diptera: Culicidae) of central Europe in view of forest communities. Acta Musei Reginaehradecensis. S.A. Suppl.: 68-70.

MOLAEI G. \& ANDREADIS T. G. 2006. Identification of avian- and mammalian-derived bloodmeals in Aedes vexans and Culiseta melanura (Diptera: Culicidae) and its implication for West Nile virus transmission in Connecticut, USA. Journal of Medical Entomology 43: 1088-1093.

MOHRIG W. 1964. Faunistisch-ökologische Untersuchungen an Culiciden der Umgebung von Greifswald. Deutsche Entomologische Zeitschrift 11: 337-352.

MOHRIG W. 1969. Die Culiciden Deutschlands. Untersuchungen zur Taxonomie, Biologie und Ökologie der einheimischen Stechmücken. Parasitologische Schriftenreihe, Heft 18. Gustav Fischer Verlag, Jena. 260 pp.

NATVIG L. R. 1948. Contributions to the knowledge of the Danish and Fennoscandian mosquitoes (Culicini). Norsk Entomologisk Tidsskrift, Suppl. 1,567 pp.

NiCOlesct G., VladimiREsCU A. \& CIOlPAN O. 2003. The distribution of mosquitoes in Romania (Diptera Culicidae). Part II: Culiseta, Coquillettidia, Ochlerotatus, Orthopodomyia and Uranotaenia. European Mosquito Bulletin 14: 1-15.

NowICKI M. 1873. Beitrage zur Kenntnis der Dipterenfauna Galiziens. Krakau, 35 pp.

OKRÓY-RYSOP G., WEGNER Z. \& STAŃCZAK J. 1991. Mosquitoes (Diptera, Culicidae) found in the coastal region from Wejherowo to Darłowo. Wiadomości Parazytologiczne 37: 45-51. [In Polish with English abstract]

PEUS F. 1950. Stechmücken. Akademische Verlagsgesellschaft, Leipzig-Wittenberg, 80 pp.

PUTKURI N., VAHERI A. \& VAPALAHTI O. 2007. Prevalence and Protein Specificity of Human Antibodies to Inkoo Virus Infection. Clinical and Vaccine Immunology 14 (12): 1555-1562.

RAMSDALE C. \& SNOW K. 1999. A preliminary checklist of European mosquitoes. European Mosquito Bulletin 5: 25-35.

RENSHAw M., SERVICE M. W. \& BIRLEy M. H. 1993. Density dependent regulation of Aedes cantans (Diptera: Culicidae) in natural and artificial populations. Ecological Entomology 18: 223-228.

RENSHAW M., SERVICE M. W. \& BIRLEY M. H. 1994. Size variation and reproductive success in the mosquito Aedes cantans. Medical and Veterinary Entomology 8: 179-186.

RETTICH F. 1982. Mosquitoes (Diptera: Culicidae) of the Mělník area (Central Bohemia). Folia Facultatis Scientiarum Naturalium Universitatis Brunensis 23 (7):111-116.

RETTICH F. 1998. Mosquito occurrence and control after catastrophic floods in the Czech Republic in the summer of 1997. Materiały XI Wrocławskiej Konferencji Parazytologicznej p.t. Integrowane metody zwalczania komarów na terenach popowodziowych. Wrocław 2 kwietnia 1998.

RETTICH F, IMRICHOVA K. \& ŚEBESTA O. 2007. Seasonal comparisons of the mosquito fauna in the flood plains of Bohemia and Moravia, Czech Republic. European Mosquito Bulletin. 23: 10-16.

RoIz D., ERITJA R., Escosa R., Lucientes J., Marques E., MELERo-AlciBar R., Rutz S. \& Moltna R. 2007. A survey of mosquitoes breeding in used tires in Spain for the detection of imported potential vector species. Journal of Vector Ecology 32:10-15. 
RYDZANICZ K. \& LONC E. 2003. Species composition and seasonal dynamics of mosquito larvae in theWroclaw, Poland area. Journal of Vector Ecology 28: 255-266.

SCHÄFER M. L. \& LUNDSTRÖM J. O. 2006. Different responses of two floodwater mosquito species, Aedes vexans and Ochlerotatus sticticus (Diptera: Culicidae), to larval habitat drying. Journal of Vector Ecology 31: 123-128.

SCHAFFNER F. 1998. A revised checklist of the French Culicidae. European Mosquito Bulletin 2: 1-9.

SÉRANDOUR J., REYNAUd S., WILlison J., PATOURAUX J., GaUdE T., Ravanel P., Lempérière G. \& Raveton M. 2008. Ubiquitous Water-Soluble Molecules in Aquatic Plant Exudates Determine Specific Insect Attraction. PLoS ONE 3(10): e3350. doi:10.1371/journal.pone.0003350

SERVICE M. W. 1968. Observations on feeding and oviposition in some British mosquitoes. Entomologia Experimentalis et Applicata 11:277-285.

SERVICE M. W. 1971a. Flight periodicities and vertical distribution of Aedes cantans (Mg.), Ae geniculatus (Ol.), Anopheles plumbeus Steph. and Culex pipiens L. (Dipt. Culicidae) in southern England. Bulletin of Entomological Research 60: 639-651.

SERVICE M. W. 1971b. Feeding behaviour and host preferences of British mosquitoes. Bulletin of Entomological Research 60: 653-661.

SERVICE M. W. 1977. Ecological and biological studies on Aedes cantans (Meig.) (Diptera: Culicidae) in Southern England. Journal of Applied Ecology 14: 159-196.

SHLENOVA M. F. \& BEI-BIENKO I. G. 1962. The age composition of populations of mass species of mosquitoes of the genus Aedes (according to observations in Byelorussia). Voprosy Obshchei Zoologii i Medicheskoi Parazitologii. Moscow, pp. 589-605.

SKIERSKA B. 1960. Investigations on mosquito fauna in Białowieża forest. Acta parasitologica Polonica 8: 7-83. [In Polish with English abstract]

SKIERSKA B. 1963. Przegląd piśmiennictwa dotyczącego komarów (Culicidae) z obszarów Polski oraz rejestracja i rejonizacja tych owadów na terenie naszego kraju. Wiadomości Parazytologiczne 9: 579-597.

SKIERSKA B. 1965 Ecological studies of the occurrence and distribution of Culicinae fauna in the coastal forest belt Ekologia Polska. Ser. A. 13: 527-573.

SKIERSKA B. 1971. Klucze do oznaczania owadów Polski. 28. Z. 9a. Komary-Culicidae. Larwy i poczwarki. PWN, Warszawa, $138 \mathrm{pp}$.

SKIERSKA B. 1974. Mosquitoes (Diptera: Culicidae) of the west part of the Wolin Island and south-east part of Uznam Island. Poznańskie Towarzystwo Przyjaciół Nauk. Wydział Matematyczno-Przyrodniczy. Prace Komisji Biologicznej. 36: 1-79. [In Polish with English summary]

SKIERSKA B. 1977. Klucze do oznaczania owadów Polski. 28, 9b. Komary - Culicidae. Postacie dojrzale. PWN, Warszawa, $120 \mathrm{pp}$.

SKIERSKA B. \& LACHMAJER J. 1960. The fauna of Culicidae in the city of Gdańsk and its environs. Bulletin of the Institute of Maritine Medicine in Gdańsk 11: 157-163.

SNOW K. \& RAMSDALE C. 1999. Distrinution chart for European mosquitoes. European Mosquito Bulletin 3: 14-31.

SPIELMAN A. 1957. The inheritance of autogeny in the Culex pipiens complex of mosquitoes. American Journal of Hygiene 65: 404-425.

SPIELMAN A. \& WONG J. 1973. Studies on autogeny in natural populations of Culex pipiens. III. Midsummer preparation for hibernation in anautogenous populations. Journal of Medical Entomology 10. 319-324.

Stage H. H., GJUllin C. M. \& Yates W. W. 1937. Flight range and longevity of flood-water mosquitoes in the lower Columbia River Valley. Journal of Economic Entomology 30: 940-945.

SUDARIĆ BOGOJEVIĆ M., JELIČIĆ Ž. \& MERDIĆ E. 2008. Seasonal population peaks observed in mosquitoes over a $10-$ year period (1995-2004) in Osijek, Croatia. The $16^{\text {th }}$ European Society for Vector Ecology Conference 2008. Fitzwilliam College, Cambridge. Conference Programme \& Abstract Book, p.65.

SZADZIEWSKA M. \& OKRÓY-RYSOP G. 1988. Research on parasitic arthropods of the Lake Żarnowieckie environs carried out in 1981-1985. Part II. Mosquitoes (Diptera: Culicidae). Bulletin of the Institute of Matitime and Tropical Medicine 39: 215-226.

TAKKEN W., GEene R., ADAM W., JETTEN T. H. \& VAN DER VELDEN J. A. 2002. Distribution and Dynamics of Larval Populations of Anopheles messeae and A. atroparvus in the delta of the Rhine and Meuse, The Netherlands. A Journal of the Human Environment. 31: 212-218.

TARWID K. 1934. Résultats de l'enquête de M. le Dr. H. Raabe sur les moustiques domestiques in Pologne en 1924 et 1925. Fragmenta Faunistica 2, 19: 161-179. [In Polish with French summary]

TARWID K. 1952. [An attempt of characterization of mosquito communities of the Kampinos Forest.] Studia Societas Scientarum Toruń., Sectio E (Zool.) 3: 1-29. [In Polish]

TIAwsirisur S., KINLEY J. R., TuCKER B. J., Evans R. B., Rowley W. A. \& PlATT K. B. 2008. Vector competence of Aedes vexans (Diptera: Culicidae) for West Nile virus and potential as an enzootic vector. Journal of Medical Entomology 43: 452-457.

TRPIŠ M. \& HORSFALL W. R. 1969. Development of Aedes sticticus (Meigen) in relation to temperature, diet, density and depth. Annales Zoologici Fennici 6: 156-160. 
TURELl M. J., LUNDSTRÖM J. O. \& NIKLASSON B. 1990. Transmission of Ockelbo virus by Aedes cinereus, Ae. communis, and Ae. excrucians (Diptera: Culicidae) collected in an enzootic area in central Sweden. Journal of Medical Entomology 27:266-268.

UDVARDY M. D. F. 1969. Dynamic Zoogeography. Van Nostrand Reinhold Company. New York. 445 pp.

VINOGRADOVA E. B. 1960. An experimental investigation of the ecological factors inducing imaginal diapause in bloodsucking mosquitoes (Diptera: Culicidae). Entomologicheskoe Obozrenie 39: 327-340. [In Russian with English summary]

VINOGRADOVA E. B. 1997. Komary kompleksa Culex pipiens v Rossii (taksonomija, rasprostranenie, èkologija, fiziologija, genetika, praktocheskoe znachenie i kontrol). Trudy ZIN RAN. Vol. 271. Sankt Peterburg, 307 pp.

VoLozINA N. V. 1961. The effect of feeding conditions and the physiological age of the females on egg maturation in Aedes mosquitoes of the communis group. In: KHELEVIN N. V. (ed.), Contributions to the knowledge of the Fauna and Flora of the Ivanovo Region, pp. 36-51. Ivanovo, USSR.. [In Russian]

WEGNER E. 1979. Changes in the structure of mosquito communities (Culicidae, Diptera) in Kampinos Forest for 40 years Memorabilia Zoologica 30: 131-144.

WEGNER E. 1982. Mosquitoes (Diptera, Culicidae) of Warsaw and Mazovia. Memorabilia zoologica 36: 201-216.

WEGNER E. 1991. Mosquitoes (Diptera: Culicidae) of the Świętokrzyski National Park. Fragmenta Faunistica 35: 65-81. [In Polish with English abstract]

WEGNER E. 1999. Autumnal development of vernal mosquitoes in Kampinos Forest near Warsaw. European Mosquito Bulletin 5: 21-24.

Wegner E. 2002. Preliminary study of mosquitoes (Diptera: Culicidae) of the Narew National Park. Fragmenta Faunistica 45: 57-65.

WEGNER E. 2004. Estimation of a risk of West Nile fever outbreak in Poland. In: BUCzEK A. \& BEASZAK Cz. (eds) Stawonogi. Interakcje pasożyt - żywiciel, pp,265-272. Liber, Lublin, 272 pp. [In Polish, English abstract]

Wegner E. 2007. Mosquitoes (Culicidae), In: Bogdanowicz W., ChudzICKa E., PilipIUK I. \& SkIBIísKA E. (eds), Fauna of Poland - characteristics and checklist of species. Vol. 2., pp. 37-39, 71-72. Muzeum i Instytut Zoologii PAN, Warszawa, XX $+506 \mathrm{pp}$.

WEGNER E. 2008. Mosquito fauna (Diptera: Culicidae) of five different towns in Poland with special reference to the occurrence of human disease vectors. Fragmenta Faunistica 51: 15-22.

Wegner E. 2009. Mosquitoes (Diptera: Culicidae) of Hlawa Lakeland Landscape Park (Poland). Dipteron 25: 69-74.

Wegner Z., KubiCA-BERnat B., StańcZAK J. \& RACEWICZ M. 1993. Fauno-Ecological study on haematophagous dipterans in surroundings of Żarnowieckie Lake in the period 1988-1991. Biuletyn Metodyczno-Organizacyjny Instytutu Medycyny Morskiej i Tropikalnej 26: 55-72.

WESENBERG-Lund C. 1921. Contributions to the biology of the Danish Culicidae. Kongelige Danske Videnskabernes Selskab. Selsk. Skrifter, Naturvidensk. Mathem. Afd., 8. Raekke, 7, 1: 1-210.

WOJNAROWICZ J. 1960. Culicinae larvae of small ponds. Polskie Archiwum Hydrobiologii 8: 183-221.

\section{STRESZCZENIE}

\section{[Przegląd gatunków komarów (Diptera: Culicidae) stwarzających najwięlssze problemy w Polsce]}

Spośród 47 gatunków komarów (Culicidae) Polski, dwanaście może stwarzać poważne problemy, gdyż są to gatunki, które wykazują większość lub wszystkie poniższe cechy: sa agresywne w stosunku do ludzi, przylatują do osiedli i domostw ludzkich i/lub pomieszczeń dla zwierząt gospodarskich, mogą rozmnożyć się do liczebności plagowych i/lub są wektorami groźnych chorób. Są to: Anopheles messae i An. atroparvus, Ochlerotatus communis, Oc. cataphylla, Oc. punctor, Oc. cantans, Oc. sticticus, Aedes cinereus, Ae. vexans, Coquillettidia richiardii, Culex pipiens i Culiseta annulata. Dla wszystkich tych gatunków omówiono zagadnienia rozprzestrzenienia (zasięgu geograficznego), fenologii w różnych warunkach klimatycznych, wymagan i preferencji siedliskowych larw i dorostych samic, behawioru, płodności i skuteczności omawianych gatunków jako transmiterów patogenów.

Większość $\mathrm{z}$ powyższych gatunków $\mathrm{w}$ strefie klimatu umiarkowanego rozwija się przynajmniej dwukrotnie w ciągu sezonu wegetacyjnego, tzn. ma więcej niż jedno pokolenie w sezonie lub też wiele pojawów. Jedynie Oc communis i Oc. cataphylla są wczesnowiosennymi gatunkami jednopokoleniowymi i okres ich lotu jest krótki (ok. 2 miesiące), choć i one w sprzyjających warunkach moga rozwijać się dwu- lub trzykrotnie w ciągu sezonu wegetacyjnego. Wielopokoleniowy Oc. punctor oraz jednopokoleniowy (ale rozwijający się 
kilkukrotnie w ciagu sezonu) Oc. cantans często rozwijają się w tych samych zbiornikach i jako dorosłe, też występują razem. Oc. cantans jest gatunkiem typowo leśnym, bardzo wrażliwym na wysychanie, który niechętnie opuszcza środowisko leśne. Oc. punctor jest dużo bardziej ekspansywny i znacznie lepiej toleruje niską wilgotność powietrza. Okres ich wysteppowania jest znacznie dłuższy niż lot Oc. communis i Oc. cataphylla. Po-powodziowe Oc. sticticus i oba gatunki z rodzaju Aedes występują wzdluż dolin dużych rzek, a ich larwy mogą rozwijać się $\mathrm{w}$ różnorodnych zbiornikach wodnych zlokalizowanych $\mathrm{w}$ rozmaitych środowiskach. Gatunkami synantropijnymi, które rozwijać się mogą w sztucznych zbiornikach wodnych, nawet mocno zanieczyszczonych, są: Culex pipiens, a zwlaszcza jego forma molestus oraz Culiseta annulata.

Stwarzające problemy gatunki komarów wykazują kilka wspólnych cech - rozwijają się kilkakrotnie w ciągu sezonu, mają duże zdolności migracyjne i są skutecznymi wektorami patogenów ludzi i zwierząt. Szerokie spectrum plastyczności środowiskowej larw nie jest cechą wyróżniającą te gatunki.

W Polsce komary uważane są za owady tylko uciążliwe (a nie szkodliwe) chociaż wiele naszych gatunków jest skutecznymi wektorami poważnych chorób ludzi i zwierząt. Niezależnie od tego, że ostatnie naturalne ogniska malarii zostaly zlikwidowane $w$ latach 60-tych ubiegłego wieku, nadal przynajmniej dwa gatunki widliszków mogą skutecznie przenosić zarodźca malarii ludzkiej. Pozostałe gatunki omówione w pracy (oprócz jednego) mogą przenosić szereg arbowirusów, a kilka gatunków filarie nicienia z rodzaju Dirofilaria. 